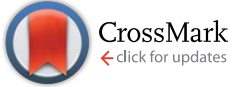

Cite this: RSC Adv., 2017, 7, 17377
Received 5th December 2016 Accepted 1st March 2017

DOI: 10.1039/c6ra27789f

rsc.li/rsc-advances

\section{Protective effects of Shanxi aged vinegar against hydrogen peroxide-induced oxidative damage in LO2 cells through Nrf2-mediated antioxidant responses}

\begin{abstract}
Ting Xia, Jiahui Yao, Jin Zhang, Yu Zheng, Jia Song and Min Wang*
Shanxi aged vinegar (SAV), a kind of typical fermented food, is one of the famous traditional vinegars in China. In this study, the antioxidant properties and hepatoprotective mechanisms of SAV on hydrogen peroxide $\left(\mathrm{H}_{2} \mathrm{O}_{2}\right)$-induced oxidative stress were investigated. Total phenolic, flavonoid contents and browning index were increased during the aging process. Gallic acid was the main component of the phenolic compounds in SAV-5. SAV-5 showed the highest antioxidant activities among all the samples. In addition, $\mathrm{H}_{2} \mathrm{O}_{2}$ was used to treat human normal hepatocyte LO2 as an inducer of oxidative stress models. Pretreatment with SAV-5 inhibited $\mathrm{H}_{2} \mathrm{O}_{2}$-induced cytotoxicity and reactive oxygen species (ROS) generation, and alleviated loss of mitochondrial membrane potential in LO2 cells. These pretreatments also significantly increased superoxide dismutase (SOD), catalase (CAT) activities and glutathione (GSH) levels. The results demonstrated that SAV-5 had a significant antioxidant effect, which could prevent oxidative damage in LO2 cells effectively. Finally, SAV-5 activated nuclear factor erythroid-2-related factor 2 (Nrf2) and up-regulated $\mathrm{NAD}(\mathrm{P}) \mathrm{H}$ quinone oxidoreductase 1 (NQO1) and heme oxygenase ( $\mathrm{HO}$ 1) protein expression in $\mathrm{H}_{2} \mathrm{O}_{2}$-treated $\mathrm{LO} 2$ cells. The protective effects of $\mathrm{SAV}$ against $\mathrm{H}_{2} \mathrm{O}_{2}$-induced oxidative damage in LO2 cells are mainly mediated by the activation of the Nrf2 antioxidant pathway. This study explored the fermented food products with antioxidant activities and the possible hepatoprotective mechanism of traditional Chinese vinegar against oxidative damage in liver cells.
\end{abstract}

\section{Introduction}

Traditional vinegars are typical fermented foods, which have been produced by the process of spontaneous fermentation for centuries. ${ }^{\mathbf{1}}$ Both grain vinegars and fruit vinegars are fermented products, and contain large amounts of active compounds. ${ }^{2}$ Shanxi aged vinegar (SAV), a well-known traditional Chinese vinegar, is brewed by traditional solid-state fermentation technology. ${ }^{3}$ During the process, it can produce rich nutrients and functional factors, which provide health and therapeutic effects. ${ }^{4}$ Among these bioactive components, such as phenols, flavonoids and melanoidins, are the main antioxidant ingredients of SAV. ${ }^{5}$ It has been reported that these antioxidants play a crucial role in the prevention of many diseases such as cardiovascular disease, hepatic damage, neurodegenerative diseases, cancer and ageing, because of their capacity for capturing, deactivating or repairing the damage caused by the free radicals that is implicated in such diseases. ${ }^{6}$ Recently, the

Key Laboratory of Industrial Fermentation Microbiology, Ministry of Education, College of Biotechnology, Tianjin University of Science and Technology, Tianjin, $P$. R. China. E-mail: minw@tust.edu.cn; Fax: +86-22-60602298; Tel: +86-22-60601256 antioxidant activities and health properties of vinegar have become the focus of extensive research.

Liver is a vital organ and plays a major role in metabolism, excretion and detoxification in the human body. Liver functions would be impaired by different factors such as infection, drugs, excessive intake of ethanol, causing accumulation of free radicals. ${ }^{7}$ Oxidative stress and liver injury are strongly associated. Oxidative stress is believed to play an important role in the pathogenesis of liver injury. ${ }^{8}$ Prevention or impairment of oxidative stress constitutes a therapeutic target to be achieved for hepatoprotection. Oxidative stress is a state of imbalance between the production of reactive oxygen species (ROS) and the cellular antioxidant defense neutralizing the reactive intermediates and triggering damage. ${ }^{9}$ Overproduction of ROS results in oxidative stress, a deleterious process that can be an important mediator of damage to cell structures, including lipids and membranes, proteins and DNA. ${ }^{10}$ The detoxication of ROS is accomplished via several enzymatic and non-enzymatic antioxidant mechanisms. ${ }^{\mathbf{1 1}}$

Nuclear factor erythroid-2-related factor $2(\mathrm{Nrf} 2)$ is a crucial transcription factor mediating protection against oxidants. ${ }^{\mathbf{1 2}}$ Under normal conditions, Nrf2 is generally inactivated in the cytoplasm by binding of Kelch-like ECH-associated protein 1 
(Keap 1). Upon stimulation by stimuli or antioxidants, Nrf2 releases from the Keap 1/Nrf2 complex and translocates to the nucleus. Then, Nrf2 binds to antioxidant-response elements (AREs) to activate the expression of downstream genes, such as heme oxygenase-1 (HO-1), NAD(P)H quinone oxidoreductase 1 (NQO1), and $\gamma$-glutamylcysteine synthetase (GCS). These genes constitute a defense system to eliminate ROS, and play an important role in protecting cells against oxidative stress. ${ }^{\mathbf{1 3 , 1 4}}$

SAV is rich in antioxidant compounds that are supplied from raw materials and microbial fermentation. ${ }^{15}$ Recent studies have demonstrated that antioxidant activities of traditional balsamic vinegar (TBV) were due to their phenolic, flavonoid contents and melanoidins. ${ }^{\mathbf{1 6 , 1 7}}$ These antioxidant ingredients interact with each other and together contribute to the total antioxidant capacity of vinegar. However, antioxidant components of SAV with different aging time, have been rarely explored. Meanwhile, both grain vinegars and fruit vinegars can improve antioxidant abilities and reduce oxidative damage. ${ }^{\mathbf{1 8 , 1 9}}$ It has been reported that vinegar could protect liver cells against oxidative damage in vivo. Antioxidant activities of vinegar may play an important role in prevention of liver damage. ${ }^{\mathbf{2 0}, 21}$

In the present study, antioxidant components and antioxidant capacity of SAV with different aging time were investigated. Then, the effects of SAV on cell viability, intracellular ROS level, mitochondrial membrane potential, and antioxidant defense systems were measured in $\mathrm{H}_{2} \mathrm{O}_{2}$-treated $\mathrm{LO} 2$ cells. Furthermore, the expression of $\mathrm{Nrf} 2$ and downstream genes were detected by western blotting to explore the antioxidant pathway of SAV. These findings would clarify the antioxidant properties and hepatoprotective mechanisms of SAV, and provide a kind of functional food against oxidative damage in human liver cells.

\section{Experimental}

\section{Chemicals and reagents}

Folin-Ciocalteu reagent, 2,2-diphenyl-1-picrylhydrazyl (DPPH), gallic acid and rutin were obtained from Sinopharm Chemical Reagent Co.,Ltd (Shanghai, China). Total antioxidant capacity assay kit with 2,2'-azino-bis(3-ethylbenzthiazoline-6-sulfonic acid) (ABTS) and ferric reducing antioxidant power (FRAP) were purchased from Beyotime Institute of Biotechnology (Shanghai, China). Hydrogen peroxide $\left(\mathrm{H}_{2} \mathrm{O}_{2}, 35\right.$ wt $\left.\%\right)$ was purchased from Alfa Aesar (Johnson Matthey Co. Lancastor, UK). Superoxide dismutase (SOD), catalase (CAT), glutathione (GSH), malonaldehyde (MDA) and protein assay kits were obtained from Nanjing Jiancheng Bioengineering Institute (Nanjing, China).

The primary antibodies against rabbit Nrf2, NQO1, HO-1 and the secondary horseradish peroxidase (HRP)-labeled goat-antirabbit antibodies, were purchased from Abcam (Cambridge, UK). Antibody against rabbit $\beta$-actin was purchased from Bioworld Technology (Nanjing, China).

\section{Samples and cell culture}

Vinegar samples, including SAV and Shanxi vinegar (SV), were purchased from local supermarkets. Human normal liver cell line LO2 was purchased from Cell Bank of Chinese Academic of Science (Shanghai, China). Cells were cultured at $37^{\circ} \mathrm{C}$ and $5 \%$ $\mathrm{CO}_{2}$ in RPMI-1640 medium (Hyclone, Logan, Utah, USA), supplemented with 10\% fetal bovine serum (FBS, Gibco, Grand Island, NY, USA), penicillin/streptomycin (1:100, Hyclone). Cells were treated with SAV at different concentration $(0-10 \mu \mathrm{L}$ $\mathrm{mL}^{-1}$ ). $20 \mathrm{mM}$ HEPES buffer was used to buffer the medium. Culture medium was changed every 2 days.

\section{Extraction and determination of high molecular weight melanoidins}

High molecular weight ( $>10 \mathrm{kDa}$ ) melanoidins were extracted from vinegar samples. Different vinegar samples of $1 \mathrm{~mL}$ were diluted to $10 \mathrm{~mL}$ with distilled water and then filtered (Whatman filter papers 40, Whatman, Maidstone, UK). One aliquot $(4 \mathrm{~mL})$ of each filtered sample was subjected to ultrafiltration with Amicon Ultra-4, regenerated cellulose $10 \mathrm{kDa}$ (Millipore, MA, USA) at $7500 \mathrm{~g}$ for $20 \mathrm{~min}$ at $4{ }^{\circ} \mathrm{C}$. The retentate, containing high molecular weight melanoidins and the filtrate containing low molecular weight compounds, such as phenols and flavonoids, were separated. The amount of high molecular weight melanoidins was determined as browning index by measuring the color as absorbance at $420 \mathrm{~nm}$ in a $1 \mathrm{~cm}$ glass cuvette. The samples were diluted in distilled water to give appropriate absorbance values. The filtrate was used to analyze for the total phenolic and flavonoid contents.

\section{Determination of total phenolic and flavonoid contents}

Total phenolic content of the filtrate was determined by the Folin-Ciocalteu method. The value for total phenolic content was expressed in terms of the gallic acid equivalent $\left(\mathrm{mg} \mathrm{mL} \mathrm{m}^{-1}\right)$. An appropriately diluted sample $(0.2 \mathrm{~mL})$ was added sequentially with Folin-Ciocalteu reagent $(0.8 \mathrm{~mL})$, $1.5 \mathrm{~mL}$ of $10 \%$ sodium carbonate. The mixture was diluted to $10.0 \mathrm{~mL}$ with distilled water and incubated at room temperature in the dark for $2 \mathrm{~h}$. Absorbance was measured at $765 \mathrm{~nm}$ using spectrophotometry. Phenolic concentration was based on a standard curve of gallic acid. The total phenolic content was expressed as gallic acid equivalent ( $\mathrm{mg}$ GAE per $\mathrm{mL}$ ).

Total flavonoid content the filtrate was measured through a colorimetric assay. The value for total flavonoid content was expressed in terms of the rutin equivalent $\left(\mathrm{mg} \mathrm{mL}^{-1}\right)$. An appropriately diluted sample $(2.0 \mathrm{~mL})$ was added to a flask and then $\mathrm{NaNO}_{2}\left(1.0 \mathrm{~mL}, 50 \mathrm{~g} \mathrm{~L}^{-1}\right)$ was added immediately. After standing for $6 \mathrm{~min}, \mathrm{Al}\left(\mathrm{NO}_{3}\right)_{3}\left(1.0 \mathrm{~mL}, 50 \mathrm{~g} \mathrm{~L}^{-1}\right)$ was added and the mixture was left to stand for another $6 \mathrm{~min}$ before $5 \mathrm{M} \mathrm{NaOH}(4.0 \mathrm{~mL})$ was added. The solution was diluted to $25.0 \mathrm{~mL}$ with distilled water and kept at room temperature in the dark for $15 \mathrm{~min}$. Absorbance was measured at $510 \mathrm{~nm}$ using spectrophotometry. Flavonoid concentration was estimated using a standard curve of rutin. The total flavonoid content was expressed as rutin equivalent (mg RE per $\mathrm{mL}$ ). 
Analysis of phenolic compounds by high-performance liquid chromatography (HPLC)

A high-performance liquid chromatography (HPLC) was used for identification and quantification of phenolic compounds in vinegar samples. SAV-5 sample $(5.0 \mathrm{~mL})$ was mixed with $15 \mathrm{~mL}$ ethyl acetate and then centrifuged at $5000 \mathrm{rpm}$ for $10 \mathrm{~min}$. The extraction was concentrated using rotary evaporation instrument $\left(35-40{ }^{\circ} \mathrm{C}\right)$ and dissolved with $2 \mathrm{~mL}$ methanol. The solution was filtered using a $0.45 \mu \mathrm{m}$ Millipore membrane and injected into HPLC system (Agilent Technologies Inc., California, USA). Chromatographic separation was performed using a reverse phase column (Luna C18 (2), $250 \times 4.6 \mathrm{~mm}, 4$ $\mu \mathrm{m}$, Phenomenex, Torrance, CA). A non-linear gradient elution of water containing $0.1 \%$ acetic acid (A) and acetonitrile (B) was used as follows: A/B $(95: 5)$ to $(30: 70)$ at $40 \mathrm{~min},(20: 80)$ at $45 \mathrm{~min},(100: 0)$ at $50 \mathrm{~min},(95: 5)$ at $51 \mathrm{~min}$, and then held for $5 \mathrm{~min}$. The flow rate was $1.00 \mathrm{~mL} \mathrm{~min}^{-1}$, the injection volume was $20 \mu \mathrm{L}$, and the detection wavelength was $278 \mathrm{~nm}$.

\section{Determination of total antioxidant capacity in vitro}

DPPH assay. The free-radical-scavenging activities of vinegar samples were measured by the DPPH assay. Briefly, $20 \mu \mathrm{L}$ of an appropriately diluted sample was added to $180 \mu \mathrm{L}$ of DPPH working solution and incubated at room temperature in the dark for $30 \mathrm{~min}$. The absorbances were measured at $517 \mathrm{~nm}$ in an automated enzyme-linked immunosorbent assay (ELISA) reader (Tecan, Salzburg, Austria). Trolox was used as a reference compound.

ABTS assay. This assay was based on the ability of different substances to scavenge the ABTS radical cation $\left(\mathrm{ABTS}^{+}\right) \cdot \mathrm{ABTS}^{+}$ was produced by ABTS stock solution and oxidant solution. The working solution was prepared by mixing the two stock solutions and allowing them to react completely in the dark at room temperature for $12 \mathrm{~h}$ before use. $10 \mu \mathrm{L}$ of an appropriately diluted sample was added to $170 \mu \mathrm{L}$ of ABTS working solution and incubated at room temperature in the dark for $6 \mathrm{~min}$. The absorbances were measured at $414 \mathrm{~nm}$ in an ELISA Plate Reader. Trolox was used as a reference compound.

FRAP assay. The reducing ability of vinegar samples was measured by FRAP assay. A working solution was freshly prepared by mixing $300 \mathrm{mM}$ acetate buffer, $10 \mathrm{mM}$ TPTZ, and $20 \mathrm{mM} \mathrm{FeCl}$ at a ratio of $10: 1: 1$. The solution was kept at $37{ }^{\circ} \mathrm{C}$ in the dark. $5 \mu \mathrm{L}$ of an appropriately diluted sample was added to $180 \mu \mathrm{L}$ of FRAP working solution and incubated at room temperature for $5 \mathrm{~min}$. The absorbances were measured at $593 \mathrm{~nm}$ in an ELISA Plate Reader. Trolox was used as a reference compound.

\section{Cell viability assay}

Cell viability was determined by Cell Counting Kit-8 (CCK-8, Dojin Laboratories, Kumamoto, Japan) colorimetric method. Cells $\left(5 \times 10^{4}\right.$ per $\left.\mathrm{mL}\right)$ were cultured in a 96 -well $(100 \mu \mathrm{L}$ per well) microplate at $37{ }^{\circ} \mathrm{C}$ in humidified $5 \% \mathrm{CO}_{2}$ for $24 \mathrm{~h}$, and treated with ligands for required time. After treatment, cells were added with $10 \mu \mathrm{L}$ CCK-8 solution, and incubated for $3 \mathrm{~h}$ at $37^{\circ} \mathrm{C}$. Absorbance in each well was quantified at $450 \mathrm{~nm}$ using an ELISA reader.

\section{Measurement of intracellular ROS generation}

The formation of intracellular ROS was measured using a fluorescent probe, $2^{\prime}, 7^{\prime}$-dichlorofluorescein-diacetate (DCFH-DA, Sigma-Aldrich, St. Louis, MO, USA). LO2 cells were cultured in 6-well plates for $24 \mathrm{~h}$, and treated with ligands for required time. After treatment, cells were added with $10 \mu \mathrm{M}$ DCFH-DA and incubated for $30 \mathrm{~min}$ in the dark. Nonfluorescent DCFH-DA dye was freely penetrated into cell membrane and enzymatically hydrolyzed by intracellular esterase to $2^{\prime}, 7^{\prime}$-dichlorodihydrofluorescein (DCFH). Then DCFH was rapidly oxidized to form highly fluorescent $2^{\prime}, 7^{\prime}$-dichlorofluorescin (DCF) in the presence of ROS. The DCF fluorescence intensity is believed to be parallel to the amount of ROS formed intracellularly. Cells were collected and resuspensed with phosphate buffer saline (PBS). The fluorescence intensity was determined by flow cytometry within $1 \mathrm{~h}$.

\section{Determination of mitochondrial membrane potential}

Fluorescent probe JC-1 (Sigma-Aldrich, St. Louis, MO, USA) was used to estimate mitochondrial membrane potential. Cells were cultured in 6-well plates and treated with different ligands. Cells were washed twice with PBS and stained with JC-1 in the dark for $30 \mathrm{~min}$ at $37{ }^{\circ} \mathrm{C}$ in humidified $5 \% \mathrm{CO}_{2}$ in complete medium. After incubation, cells were washed twice with PBS and immediately observed under a fluorescence microscopy within $1 \mathrm{~h}$.

\section{Determination of antioxidant enzymes and GSH and lipid peroxidation}

Antioxidant enzymes (CAT and SOD) and non-enzymatic antioxidant (GSH) in liver cells were measured using commercial kits according to the enclosed guidelines. The absorbance of each well was measured by an ELISA reader or spectrophotometry. SOD and CAT levels were expressed as U per mgprot, and GSH level was expressed as $\mu \mathrm{mol}$ per gprot.

MDA, a break down product of the oxidative degradation of cell membrane lipids, has been generally considered as an indicator of lipid peroxidation. Lipid peroxidation in liver cells was determined by a MDA assay reagent kit according to the manufacturer's instruction. Lipid peroxidation level was assayed by the measurement of thiobarbituric acid-reactive substance (TBARS) level and was expressed as MDA level. The spectrophotometric absorbance was assessed at $532 \mathrm{~nm}$ using spectrophotometry. The MDA level was expressed as nmol per mgprot.

\section{Western blot analysis}

After treatment, cells were collected and lysed for $30 \mathrm{~min}$ in RIPA buffer. The concentration of protein was measured by BCA reagent. For each sample, $20 \mu \mathrm{g}$ of total protein extracts were diluted in SDS-sample buffer, denatured at $98{ }^{\circ} \mathrm{C}$ for $5 \mathrm{~min}$ and separated with a $12 \%$ sodium dodecyl sulfate-polyacrylamide gel electrophoresis (SDS-PAGE) gel. After electrophoresis, the 
proteins were transferred to a polyvinylidene fluoride (PVDF) membrane (Millipore, MA, USA). The membrane was blocked with $5 \%$ milk for $1 \mathrm{~h}$ in TBST (20 mM Tris-HCl, pH 7.4, $150 \mathrm{mM}$ $\mathrm{NaCl}, 0.1 \%$ Tween-20), and incubated overnight with primary antibodies. After washing with TBST, the membranes were incubated with horseradish peroxidase-conjugated secondary antibodies for $1 \mathrm{~h}$ at room temperature and washed. The immunoreactive bands were detected using an enhanced chemiluminescence (ECL, Thermo Scientific, Vantaa, Finland). Each membrane was stripped and re-probed with anti-actin antibody to ensure equal protein loading.

\section{Statistical analyses}

Results were presented as mean \pm standard deviation (S.D.). Analysis of variance was performed by one-way ANOVA procedures, using Prism 5.03 (GraphPad Software Inc., San Diego, CA, USA). Significant differences were calculated according to the Bonferroni post hoc test. A $P$-value $<0.05$ was considered statistically significant.

\section{Results and discussion}

\section{Total phenolic, flavonoid contents and browning index}

Phenols, flavonoids and melanoidins were considered the main bioactive compounds and had antioxidant properties in food. ${ }^{22-24}$ It has been reported that these antioxidant compounds were indicated to a powerful scavenging ability of free radicals and had a significant contribution to free radicalinduced disease. ${ }^{25-27}$ As shown in Table 1, total phenolic content was determined by Folin-Ciocalteu reagent. The concentration of phenolics ranged between $0.665 \pm 0.020 \mathrm{mg}$ GAE per $\mathrm{mL}$ and $3.265 \pm 0.278 \mathrm{mg}$ GAE per $\mathrm{mL}$. A significant difference was found in total phenolic content between the two samples $(P<0.05)$. The phenolic content of SAV-5 was the highest among all the vinegar samples. Total flavonoid content was determined using spectrophotometric method with aluminum chloride. The concentration of flavonoids in different samples was in the range of $0.446 \pm 0.070 \mathrm{mg} \mathrm{RE}$ per $\mathrm{mL}$ to $3.008 \pm 0.063 \mathrm{mg}$ RE per $\mathrm{mL}$. The flavonoid content of SAV-5 was significantly higher than that of other samples $(P<$ 0.05). The results suggest that total phenolic and flavonoid contents are increased in a time-dependent manner. In addition, the browning index (A420 nm) of high molecular weight melanoidins ranged between $0.528 \pm 0.010$ and $1.245 \pm$ 0.059 . There was no significant difference in the browning index between SAV-5 (1.236 \pm 0.029$)$ and SAV-4 (1.245 \pm 0.059$)$. The browning index of SAV-4 and SAV-5 significantly was higher than that of other samples $(P<0.05)$. This increment in the browning index indicates that the Maillard reaction continues during aging process of 5 years, being favored by the synthesis of new polymeric compounds.

\section{Major phenolic compounds of SAV-5}

Major phenolic compounds of SAV-5 were analyzed by HPLC. As shown in Table 2, these compounds were identified as gallic acid, catechins, chlorogenic acid, caffeic acid, syringic acid, pcoumaric acid, ferulic acid and rutin. The concentration of gallic acid was $114.67 \pm 3.88 \mathrm{mg} \mathrm{\textrm {L } ^ { - 1 }}$, followed by catechins $\left(86.98 \pm 0.36 \mathrm{mg} \mathrm{L}^{-1}\right)$ and caffeic acid $\left(53.69 \pm 1.87 \mathrm{mg} \mathrm{L}^{-1}\right)$, which exhibited antioxidant activities and possessed a protective effect against oxidative damage. ${ }^{28}$ The results indicate that gallic acid is the main component of the phenolic compounds in SAV-5.

\section{Total antioxidant capacity in vitro}

DPPH and ABTS are both stable free radicals, which are used for the antioxidant activities test. ${ }^{29}$ FRAP measures the reducing capability based upon the ferric ion, which is used for another

Table 2 Retention time and content of phenolic compounds in $\mathrm{SAV}-5^{a}$

\begin{tabular}{lcc}
\hline Compounds & Retention time $(\mathrm{min})$ & Content $\left(\mathrm{mg} \mathrm{L}^{-1}\right)$ \\
\hline Gallic acid & $6.34 \pm 0.11$ & $114.67 \pm 3.88$ \\
Catechins & $18.86 \pm 0.25$ & $86.98 \pm 0.36$ \\
Chlorogenic acid & $21.29 \pm 0.14$ & $\mathrm{ND}$ \\
Caffeic acid & $23.09 \pm 0.18$ & $53.69 \pm 1.87$ \\
Syringic acid & $26.30 \pm 0.09$ & $8.94 \pm 0.65$ \\
p-Coumaric acid & $32.34 \pm 1.00$ & $11.24 \pm 0.45$ \\
Ferulic acid & $37.60 \pm 0.24$ & $11.23 \pm 0.81$ \\
Rutin & $40.10 \pm 0.13$ & $\mathrm{ND}$ \\
Gallic acid & $6.34 \pm 0.11$ & $114.67 \pm 3.88$
\end{tabular}

${ }^{a}$ Each value in the table is represent mean $\pm \mathrm{SD}(n=3)$. ND indicates not detected.

Table 1 Total phenolic, flavonoid contents and browning index of vinegar samples ${ }^{a}$

\begin{tabular}{lllll}
\hline Samples & $\begin{array}{l}\text { Aging time } \\
\text { (month) }\end{array}$ & $\begin{array}{l}\text { Total phenolic content } \\
(\mathrm{mg} \mathrm{GAE} \mathrm{per} \mathrm{mL)}\end{array}$ & $\begin{array}{l}\text { Total flavonoids content } \\
\text { (mg RE per mL) }\end{array}$ & $\begin{array}{l}\text { Browning index } \\
(\text { OD } 420 \mathrm{~nm})\end{array}$ \\
\hline SV-1 & 6 & $0.665 \pm 0.020^{\mathrm{a}}$ & $0.446 \pm 0.070^{\mathrm{a}}$ & $0.528 \pm 0.010^{\mathrm{a}}$ \\
SAV-2 & 12 & $1.149 \pm 0.046^{\mathrm{b}}$ & $1.058 \pm 0.033^{\mathrm{b}}$ & $0.557 \pm 0.011^{\mathrm{a}}$ \\
SAV-3 & 36 & $2.054 \pm 0.051^{\mathrm{c}}$ & $2.805 \pm 0.062^{\mathrm{c}}$ & $0.999 \pm 0.016^{\mathrm{b}}$ \\
SAV-4 & 60 & $2.719 \pm 0.207^{\mathrm{d}}$ & $3.008 \pm 0.062^{\mathrm{d}}$ & $1.245 \pm 0.059^{\mathrm{c}}$ \\
SAV-5 & 96 & $3.265 \pm 0.278^{\mathrm{e}}$ & & $1.236 \pm 0.029^{\mathrm{c}}$
\end{tabular}

${ }^{a}$ Each value in the table is represented as mean \pm S.D. $(n=3)$. Significant differences are evaluated using analysis of variance (ANOVA) with Duncan multiple comparison test. The same alphabetical code in the same column indicates no significant difference $(P>0.05)$, while the different alphabetical code in the same column indicates significant difference $(P<0.05)$. 
index for evaluating the antioxidant activities. ${ }^{30}$ In vitro studies have shown that the antioxidant activity of TBV measured by $\mathrm{DPPH}$ and ABTS were $13.59 \pm 6.6 \mu \mathrm{M}$ TEs per $\mathrm{mL}$ and $33.52 \pm$ $19.3 \mu \mathrm{M}$ TEs per $\mathrm{mL}$, respectively. ${ }^{31}$ In this study, total antioxidant activities of vinegar samples were evaluated by DPPH, ABTS and FRAP assays. Scavenging activity of trolox was used as the standard. $.^{32} \mathrm{DPPH}, \mathrm{ABTS}$ and FRAP units of vinegar samples were calculated as trolox equivalent antioxidant capacity (TEAC). As shown in Table 3, the TEAC values of vinegar samples in DPPH assay were gradually increased with the aging time. The radical scavenging ability of vinegar in ABTS and FRAP assays showed the antioxidant capacity similar to that in DPPH assay. Meanwhile, the results showed that the TEAC values of SAV-5 in DPPH, ABTS and FRAP assays were $24.29 \pm$ 1.81 TEAC, $13.54 \pm 0.22$ TEAC, $18.65 \pm 0.11$ TEAC, respectively, which were significantly higher than those of other samples $(P<$ 0.05). The results imply that SAV-5 can efficiently scavenge various free radicals in different assays and exhibit the highest antioxidant activity in vitro. Then, SAV-5 was selected for evaluation of the potential protective effects in $\mathrm{LO} 2$ cells.

\section{SAV-5 protected LO2 cells against $\mathrm{H}_{2} \mathrm{O}_{2}$-induced cytotoxicity}

In order to eliminate the interference of acetic acid, $20 \mathrm{mM}$ HEPES buffer was used to buffer the medium. ${ }^{33}$ The effects of

Table 3 Total antioxidant capacity of vinegar samples measured by three different assays ${ }^{a}$

\begin{tabular}{llcc} 
Samples & DPPH TEAC value* & FRAP TEAC value* & ABTS TEAC value* \\
\hline SV-1 & $11.51 \pm 1.00^{\mathrm{a}}$ & $2.99 \pm 0.32^{\mathrm{a}}$ & $4.94 \pm 0.22^{\mathrm{a}}$ \\
SAV-2 & $14.64 \pm 0.99^{\mathrm{b}}$ & $4.05 \pm 0.52^{\mathrm{b}}$ & $9.29 \pm 0.31^{\mathrm{b}}$ \\
SAV-3 & $16.21 \pm 0.40^{\mathrm{c}}$ & $8.91 \pm 0.31^{\mathrm{c}}$ & $13.04 \pm 0.36^{\mathrm{c}}$ \\
SAV-4 & $16.90 \pm 1.21^{\mathrm{c}}$ & $11.78 \pm 0.25^{\mathrm{d}}$ & $15.18 \pm 0.42^{\mathrm{d}}$ \\
SAV-5 & $24.29 \pm 1.81^{\mathrm{d}}$ & $13.54 \pm 0.22^{\mathrm{e}}$ & $18.65 \pm 0.11^{\mathrm{e}}$
\end{tabular}

$a *$ Value are expressed as mmol of TEAC per liter of samples. Data represent mean \pm S.D. $(n=3)$. Significant differences are evaluated using analysis of variance (ANOVA) with Duncan multiple comparison test. The same alphabetical code in the same column indicates no significant difference $(P>0.05)$, while the different alphabetical code in the same column indicates significant difference $(P<0.05)$.
SAV-5 on cell viability in human liver cells were investigated by CCK-8 assay. LO2 cells were treated with increasing concentrations of SAV-5 for $24 \mathrm{~h}$. As shown in Fig. 1A, cell viability was not significantly changed when LO2 cells were treated with $2.5-10 \mu \mathrm{L}$ $\mathrm{mL}^{-1}$ vinegar. These results suggest that vinegar has no cytotoxic effect on human normal liver cells at the selected concentrations.

A reliable in vitro cellular model for the study of oxidative damage has been proved invaluable experimental tools in basic research. ${ }^{34} \mathrm{H}_{2} \mathrm{O}_{2}$ is a major component of ROS, which is used extensively as an inducer in oxidative stress models. ${ }^{35}$ In this study, we used $\mathrm{H}_{2} \mathrm{O}_{2}$ to establish an oxidative injury cell model. LO2 cells were exposed to $\mathrm{H}_{2} \mathrm{O}_{2}$ at different concentrations $(0-400 \mu \mathrm{M})$ for 6 h. As shown in Fig. 1B, survival of LO2 cells was significantly decreased in a dose-dependent manner. Cell viability was reduced to $61.01 \pm 4.38 \%$ in $200 \mu \mathrm{M} \mathrm{H}_{2} \mathrm{O}_{2}$-treated group. According to previous studies, $\mathrm{H}_{2} \mathrm{O}_{2}$-injured cellular models were established as the cell viability reduced to $50-70 \% .^{36}$ Therefore, treatment of 200 $\mu \mathrm{M} \mathrm{H}_{2} \mathrm{O}_{2}$ for $6 \mathrm{~h}$ was chosen for further experiments.

Next, we evaluated the potential protective effects of SAV-5 against oxidative stress-induced injury in LO2 cells. Cells were pretreated with various concentrations of vinegar and $10 \mu \mathrm{g}$ $\mathrm{mL}^{-1}$ vitamin $\mathrm{C}$ for $24 \mathrm{~h}$, and then $\mathrm{H}_{2} \mathrm{O}_{2}$-induced cytotoxicity in LO2 cells was investigated. Vitamin $\mathrm{C}$, a highly effective antioxidant, is often used as positive control to protect cells against $\mathrm{H}_{2} \mathrm{O}_{2}$-induced cell death. ${ }^{37}$ As shown in Fig. 1C, after exposure to $200 \mu \mathrm{M} \mathrm{H}_{2} \mathrm{O}_{2}$ for $6 \mathrm{~h}$, cell viability was significantly decreased compared to the control group. However, pretreatment with SAV-5 attenuated $\mathrm{H}_{2} \mathrm{O}_{2}$-induced cell death in a dose-dependent manner. $10 \mu \mathrm{L} \mathrm{mL}{ }^{-1} \mathrm{SAV}-5$ and $10 \mu \mathrm{g} \mathrm{mL}^{-1}$ vitamin $\mathrm{C}$ restored cell viability up to $91.73 \pm 4.41 \%$ and $86.40 \pm 4.35 \%$, respectively. At $10 \mu \mathrm{L} \mathrm{mL}^{-1}$, the protective effect of SAV- 5 was similar to that of $10 \mu \mathrm{g} \mathrm{mL}^{-1}$ vitamin C. $10 \mu \mathrm{L} \mathrm{mL}^{-1} \mathrm{SAV}-5$ showed the best protective effect comparable to other concentrations of vinegar. These results indicate that SAV-5 can ameliorate $\mathrm{H}_{2} \mathrm{O}_{2}$-induced cytotoxicity and exhibit hepatoprotective activity in $\mathrm{LO} 2$ cells.

\section{SAV-5 inhibited $\mathrm{H}_{2} \mathrm{O}_{2}$-induced ROS generation and lipid peroxidation in $\mathrm{LO} 2$ cells}

ROS are by products of aerobic metabolism, which is often associated with the principle of oxidative stress. ${ }^{38}$ Oxidative
A

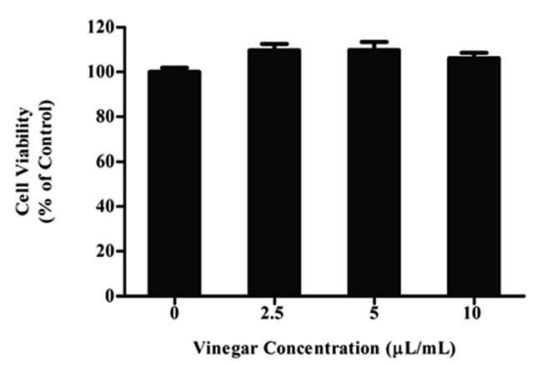

B

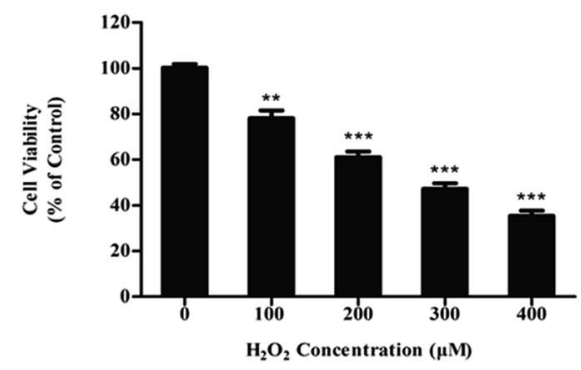

C

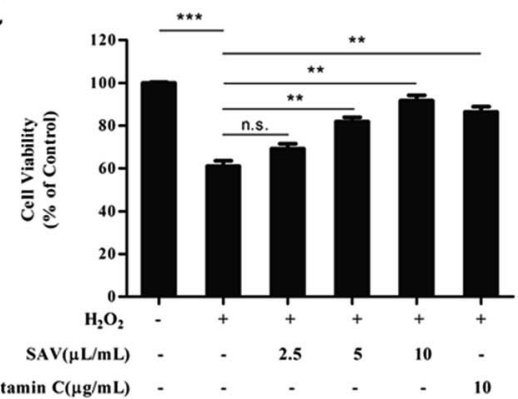

Fig. 1 Protective effects of SAV-5 against $\mathrm{H}_{2} \mathrm{O}_{2}$-induced cell death in LO2 cells. (A) LO2 cells were treated with various concentrations of vinegar for $24 \mathrm{~h}$. (B) Cells were treated with increasing concentrations of $\mathrm{H}_{2} \mathrm{O}_{2}$ for $6 \mathrm{~h}$. (C) Cells were pretreated with various concentrations of vinegar and $10 \mu \mathrm{g} \mathrm{mL}^{-1}$ vitamin $\mathrm{C}$ for $24 \mathrm{~h}$, and then treated with $200 \mu \mathrm{M} \mathrm{H}_{2} \mathrm{O}_{2}$ for $6 \mathrm{~h}$. Vitamin $\mathrm{C}$ was used as positive control. Cell viability was measured by CCK- 8 assay. Data are presented as mean \pm S.D. $(n=3)$ for each group. ${ }^{* *} p<0.01, * * * p<0.001$. 
stress is the net result of an imbalance between production and destruction of ROS, which is involved in over 100 diseases, as their cause or consequence. ${ }^{39,40}$ To evaluate the levels of intracellular ROS in $\mathrm{H}_{2} \mathrm{O}_{2}$-treated $\mathrm{LO} 2$ cells, a DCFH-DA fluorescent probe was used. The results showed that the DCF fluorescence intensity in $\mathrm{H}_{2} \mathrm{O}_{2}$-treated group was significantly increased to $189.80 \pm 15.34 \%$ compared with that in the control group. However, the fluorescence intensity was notably reduced to $146.32 \pm 14.98 \%$ and $121.41 \pm 13.16 \%$, respectively, in LO2 cells pretreated with $5 \mu \mathrm{L} \mathrm{mL}{ }^{-1}$ and $10 \mu \mathrm{L} \mathrm{mL}^{-1}$ vinegar. Pretreatment with $10 \mu \mathrm{L} \mathrm{mL}{ }^{-1} \mathrm{SAV}-5$ showed the highest scavenging activity of intracellular ROS (Fig. 2A and B). Exogenous $\mathrm{H}_{2} \mathrm{O}_{2}$ treatment results in accumulation of intracellular ROS, which play an important role in cell death, differentiation, contraction and cell proliferation. ${ }^{41}$ These results imply that pretreatment with SAV-5 can inhibit $\mathrm{H}_{2} \mathrm{O}_{2}$-induced ROS generation and protect the cells from intracellular ROS damage.

MDA, a degradation product of membrane lipid peroxidation, is one of the primary events in oxidative damage. MDA level is commonly known as a marker of oxidative stress. ${ }^{42}$ As shown in Fig. 2C, accompany with ROS generation, MDA level in $\mathrm{H}_{2} \mathrm{O}_{2}$-treated group was also significantly increased compared with that in the control group. However, pretreatment with $5 \mu \mathrm{L}$ $\mathrm{mL}^{-1}$ and $10 \mu \mathrm{L} \mathrm{mL} \mathrm{L}^{-1}$ vinegar markedly suppressed the overproduction of MDA level in $\mathrm{H}_{2} \mathrm{O}_{2}$-treated $\mathrm{LO} 2$ cells.
Pretreatment with $10 \mu \mathrm{L} \mathrm{mL}{ }^{-1} \mathrm{SAV}-5$ showed the strongest inhibitory effect with MDA level decreasing to $6.872 \pm 1.117$ $\mathrm{nmol} \mathrm{mg}^{-1}$ protein. Excessive ROS causes lipid peroxidation, denature proteins and mutate DNA, and eventually leads to cell apoptosis. ${ }^{43}$ Collectively, these results indicate that SAV-5 ameliorates the products of intracellular ROS and lipid peroxidation, and protects the fragile cell membrane against oxidative damage in $\mathrm{H}_{2} \mathrm{O}_{2}$-treated $\mathrm{LO} 2$ cells.

\section{SAV-5 attenuated $\mathrm{H}_{2} \mathrm{O}_{2}$-induced loss of mitochondrial membrane potential}

In mammalian cells mitochondria are the major source of ROS. ${ }^{44}$ Mitochondrial membrane potential $\left(\Delta \Psi_{\mathrm{m}}\right)$ is fundamental to the maintenance of mitochondrial physiological function. ${ }^{45}$ Excessive ROS accumulation can induce mitochondrial damage and lead to a collapse of $\Delta \Psi_{\mathrm{m}} \cdot{ }^{46}$ In this study, we used the sensitive fluorescent probe JC- 1 to examine the $\Delta \Psi_{\mathrm{m}}$ by fluorescent microscopy. As shown in Fig. 3A, exposure of hepatocytes to $200 \mu \mathrm{M} \mathrm{H}_{2} \mathrm{O}_{2}$ increased the amount of green fluorescence, signified by the shift in the fluorescence spectrum of JC-1 from an aggregated form with orange-red fluorescence to a monomeric form with green fluorescence. In contrast, pretreatment with vinegar decreased the green fluorescence signals compared to $\mathrm{H}_{2} \mathrm{O}_{2}$ treatment alone. The red/green

A
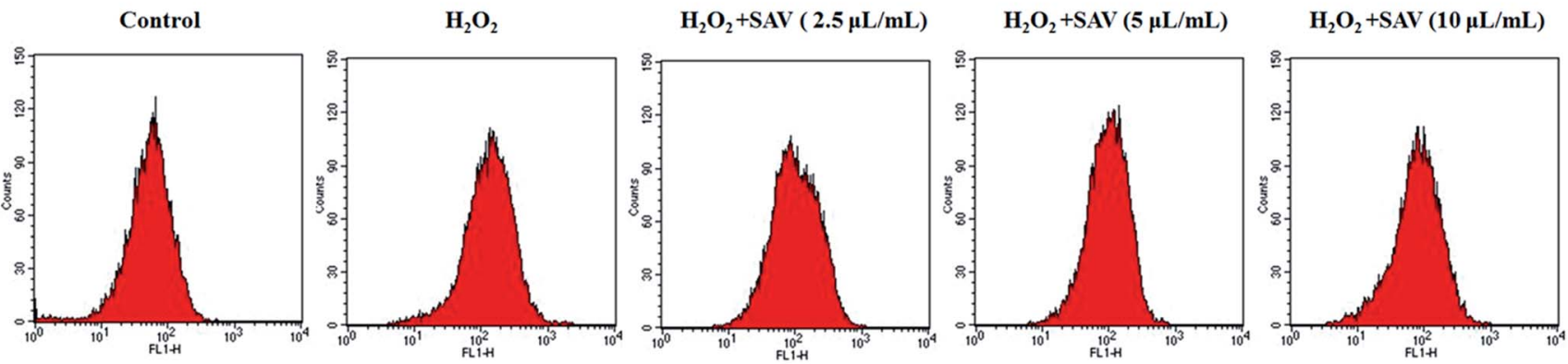

B
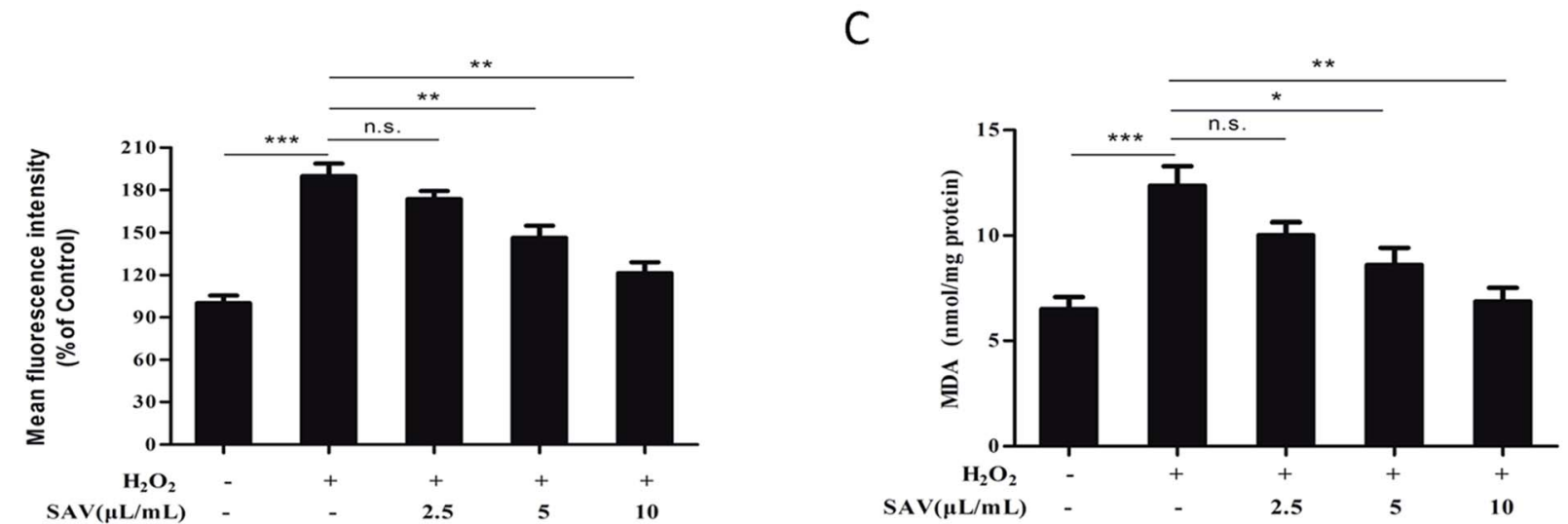

Fig. 2 SAV-5 reduced the levels of intracellular ROS and MDA in $\mathrm{H}_{2} \mathrm{O}_{2}$-treated $\mathrm{LO} 2$ cells. Cells were pretreated with various concentrations of vinegar for $24 \mathrm{~h}$ and then treated with $200 \mu \mathrm{M} \mathrm{H}_{2} \mathrm{O}_{2}$ for $6 \mathrm{~h}$. (A) Cells were stained with DCFH-DA. The DCF fluorescence intensity was measured using flow cytometry. (B) The mean fluorescence intensity reflects intracellular ROS levels. (C) MDA level was measured with microplate reader. Data are presented as mean \pm S.D. $(n=3)$ for each group. ${ }^{*} p<0.05, * * p<0.01, * * * p<0.001$. 
A
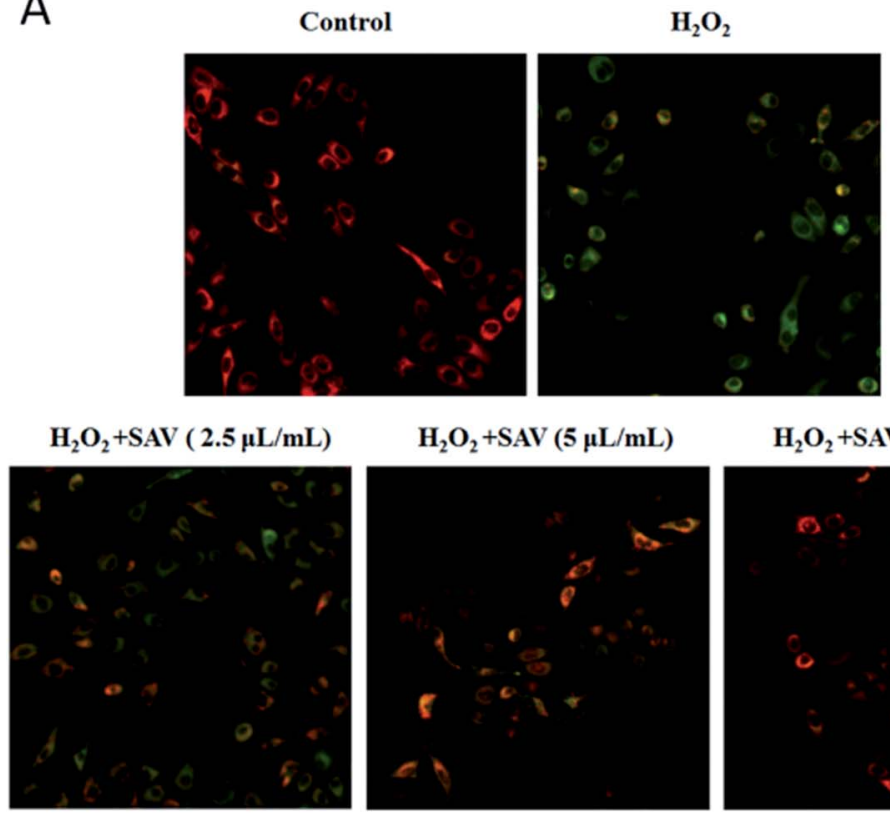

$\mathrm{H}_{2} \mathrm{O}_{2}+\mathrm{SAV}(10 \mu \mathrm{L} / \mathrm{mL})$

B

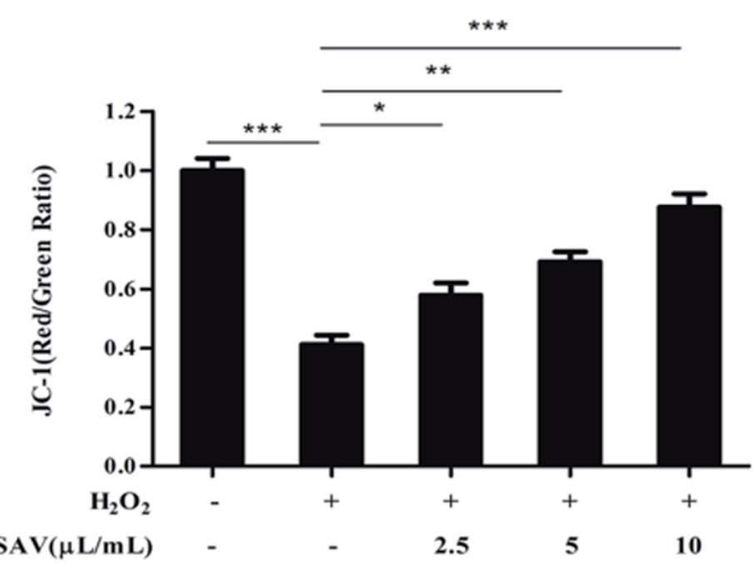

Fig. 3 SAV-5 attenuated $\mathrm{H}_{2} \mathrm{O}_{2}$-triggered loss of $\Delta \Psi_{\mathrm{m}}$. Cells were treated with different ligands as previously described and stained with JC-1. (A) The fluorescence intensity was evaluated using fluorescent microscopy (bar $=10 \mu \mathrm{M}$ ). (B) The ratio of red/green reflects mitochondrial membrane potential $\left(\Delta \Psi_{\mathrm{m}}\right)$. The corresponding histograms were quantified by Image J. All data are represented as mean \pm S.D. $(n=3)$ for each group. $* p<0.05, * * p<0.01, * * * p<0.001$

fluorescence intensity ratio indicates $\Delta \Psi_{\mathrm{m}}$ levels. $\Delta \Psi_{\mathrm{m}}$ depolarization is indicated by a decrease in the red/green fluorescence intensity ratio. ${ }^{47}$ As shown in Fig. $3 \mathrm{~B}, \mathrm{H}_{2} \mathrm{O}_{2}$ treatment caused a dissipation of $\Delta \Psi_{\mathrm{m}}$, whereas pretreatment with SAV-5 significantly attenuated the loss of $\Delta \Psi_{\mathrm{m}}$ in a dose-dependent manner. These results indicate that SAV-5 can restore $\mathrm{H}_{2} \mathrm{O}_{2}$ triggered loss of $\Delta \Psi_{\mathrm{m}}$ and stabilize mitochondrial function.

SAV-5 enhanced antioxidant enzymes activities and glutathione (GSH) level in $\mathrm{H}_{2} \mathrm{O}_{2}$-treated $\mathrm{LO} 2$ cells

Generally, exogenous $\mathrm{H}_{2} \mathrm{O}_{2}$ treatment can increase the levels of intracellular ROS and cause cellular oxidative damage. ${ }^{48}$ Nevertheless, excessive ROS can be eliminated by hepatocyte antioxidant defense which induced by both enzymatic and nonenzymatic mechanisms. ${ }^{49,50}$ In order to evaluate the effects of SAV-5 on antioxidant defense systems, SOD, CAT activities and GSH level were detected in $\mathrm{H}_{2} \mathrm{O}_{2}$-treated $\mathrm{LO} 2$ cells. SOD and CAT are two important antioxidant enzymes for preventing oxidative damage. ${ }^{51} \mathrm{GSH}$ is a major tissue antioxidant, which is maintained in the reduced form by glutathione reductase and provides reducing equivalents for the glutathione peroxidase (GPx) catalyzed reduction. ${ }^{52}$ The results showed that SOD, CAT activities and GSH level in $\mathrm{H}_{2} \mathrm{O}_{2}$-treated group were markedly decreased compared with that in control group. However, pretreatment with SAV-5 increased the activities of SOD and CAT, although the effect of $2.5 \mu \mathrm{L} \mathrm{mL}{ }^{-1}$ vinegar was not statistically significant (Fig. 4A and B). Consistent with antioxidant enzymes activities, GSH level was also significantly increased in $\mathrm{H}_{2} \mathrm{O}_{2}$-treated $\mathrm{LO} 2$ cells pretreated with SAV-5 
A

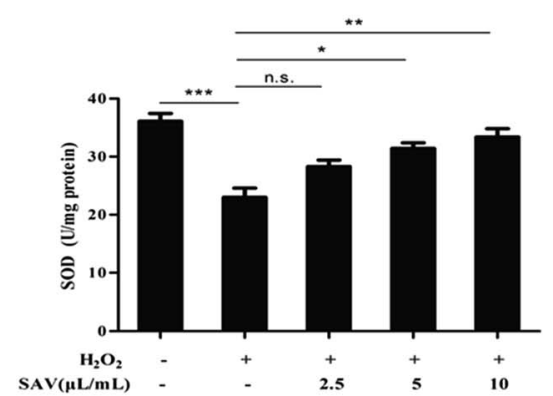

B

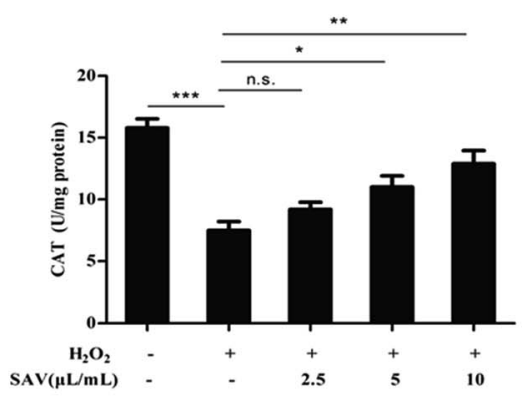

C

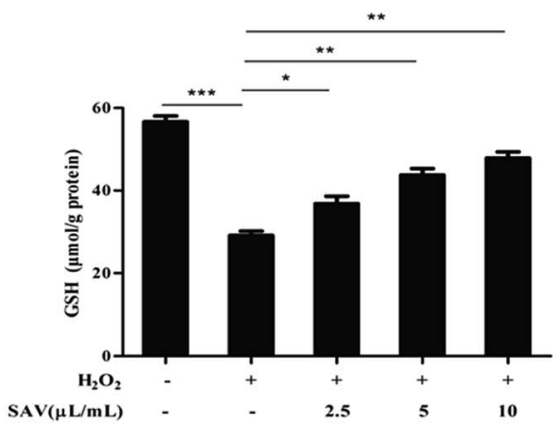

Fig. 4 SAV-5 restored SOD, CAT activities and GSH level in $\mathrm{H}_{2} \mathrm{O}_{2}$-treated LO2 cells. Cells were treated with different ligands as previously described. SOD activity (A), CAT activity (B) and GSH level (C) were measured with microplate reader. Data are expressed as mean \pm S.D. $(n=3)$. $* p<0.05, * * p<0.01, * * * p<0.001$.

(Fig. 4C). Collectively, pretreatment with vinegar effectively restored SOD, CAT activities and GSH level in $\mathrm{H}_{2} \mathrm{O}_{2}$-treated $\mathrm{LO} 2$ cells. These data suggest that SAV-5 enhances the antioxidant status that can prevent oxidative damage in $\mathrm{H}_{2} \mathrm{O}_{2}$-treated $\mathrm{LO} 2$ cells.

\section{SAV-5 up-regulated Nrf2-mediated antioxidant gene expression}

To further clarify underlying antioxidant mechanisms of vinegar, the expression levels of Nrf2 and phase II detoxifying enzyme were analyzed by western blotting. Nrf2 is the key transcription factor regulating an adaptive response to oxidative stress. When challenged by oxidative stress, Nrf2 can quickly translocate into the nucleus and elicit the antioxidant response. ${ }^{53,54}$ In the present study, the results showed that the expression level of Nrf2 was increased when LO2 cells were pretreated with vinegar (Fig. 5A). Then, the free Nrf2 is combined with an antioxidant response element (ARE) and activates important antioxidant proteins and phase II detoxifying enzymes, such as HO-1 and NQO1. ${ }^{55} \mathrm{HO}-1$ is an inducible

B
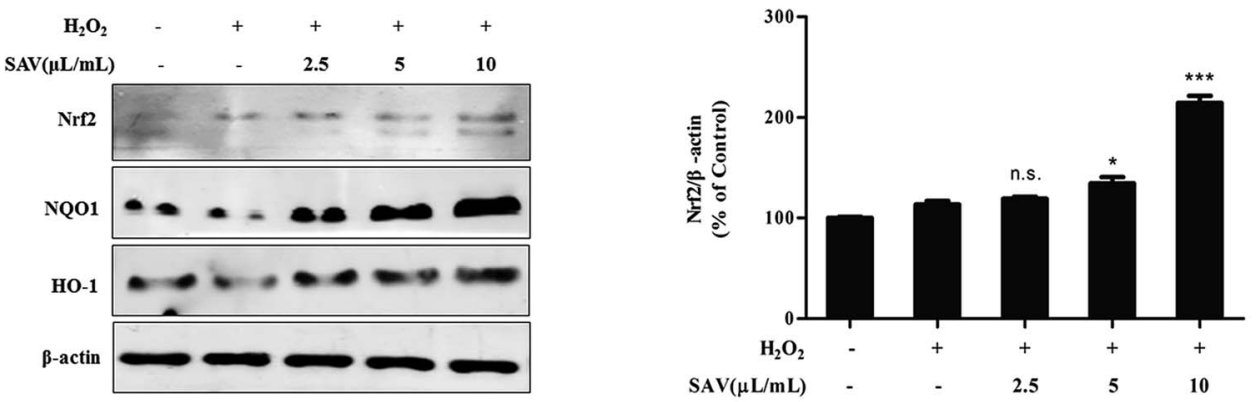

C

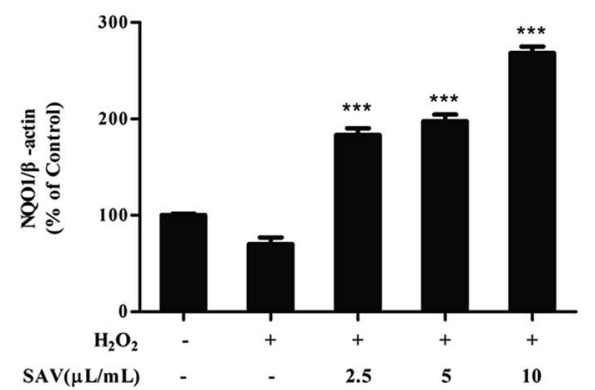

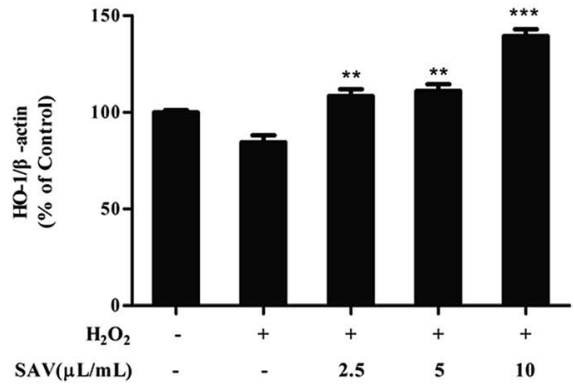

Fig. 5 Effects of SAV-5 on expression of Nrf2 and downstream genes in $\mathrm{H}_{2} \mathrm{O}_{2}$-treated LO2 cells. Cells were treated with different ligands as previously described. (A) The expression levels of Nrf2-mediated antioxidant proteins were detected by western blot analysis. (B) Quantification of Nrf2 protein expression. (C) Quantification of NQO1 protein expression. (D) Quantification of HO-1 protein expression. Data are expressed as mean \pm S.D. $(n=3) .{ }^{*} p<0.05, * * p<0.01$, and $* * * p<0.001$, comparing to $\mathrm{H}_{2} \mathrm{O}_{2}$ group. 
cytoprotective enzyme that can catalyze the rate-limiting step to degrade free heme into bilirubin, which could serve as an endogenous antioxidant. ${ }^{56} \mathrm{NQO} 1$ is a cytosolic flavoprotein that catalyzes the two electron reduction of quinoid compounds using $\mathrm{NADH}$ and/or NADPH as electron donors. ${ }^{57} \mathrm{HO}-1$ and NQO1 genes are crucial mediators in maintaining antioxidant homeostasis during cellular stress. ${ }^{58}$ As shown in Fig. 5B, after treatment with $\mathrm{H}_{2} \mathrm{O}_{2}$, the expression levels of HO-1 and NQO1 were decreased compared to the control group. However, pretreatment with SAV-5 prior to $\mathrm{H}_{2} \mathrm{O}_{2}$ exposure significantly increased the expression levels of these proteins. Collectively, the results demonstrated that SAV-5 up-regulated the expression of antioxidants and phase II detoxifying enzymes such as HO-1 and NQO1, which were regulated by Nrf2 signaling pathway. These finding suggest that the hepatoprotective effects of SAV against $\mathrm{H}_{2} \mathrm{O}_{2}$-induced oxidative damage in LO2 cells are mainly mediated by the activation of Nrf2 pathway.

\section{Conclusions}

In the present study, the antioxidant activities and hepatoprotective mechanisms of vinegar were assessed. SAV-5 was rich in phenolic and flavonoid compounds, and had the highest antioxidant activities among all the samples. Meanwhile, SAV-5 attenuated $\mathrm{H}_{2} \mathrm{O}_{2}$-induced cytotoxicity in human LO2 cells and exhibited protective effects by inhibiting intracellular ROS generation, restoring the loss of $\Delta \Psi_{\mathrm{m}}$, and enhancing antioxidant defense systems under $\mathrm{H}_{2} \mathrm{O}_{2}$-induced oxidative damage. In addition, SAV-5 up-regulated the expression levels of Nrf2 and downstream genes (NQO1 and $\mathrm{HO}-1$ ) in $\mathrm{H}_{2} \mathrm{O}_{2}$-treated $\mathrm{LO} 2$ cells. Collectively, the results suggest that SAV can protect human liver cells against $\mathrm{H}_{2} \mathrm{O}_{2}$-induced oxidative damage via antioxidant activity and Nrf2-mediated antioxidant responses.

\section{Conflict of interest}

The authors have declared no conflict of interest.

\section{Acknowledgements}

This work was supported by the National Natural Science Foundation of China (81600126, 31471722 and 31671851), the Ministry of Science and Technology of China (2013AA102106, 2016YFD0400505), Program for Changjiang Scholars and Innovative Research Team in University (IRT15R49).

\section{References}

1 F. Chen, L. Li, J. Qu and C. Chen, in Vinegars of the World, ed. L. Solieri and P. Giudici, Springer Milan, Milano, 2009, vol. 15, pp. 243-259.

2 H. Chen, T. Chen, P. Giudici and F. Chen, Compr. Rev. Food Sci. Food Saf., 2016, 15, 1124-1138.

3 Z. Nie, Y. Zheng, H. Du, S. Xie and M. Wang, Food Microbiol., 2015, 47, 62-68.

4 A. Samad, A. Azlan and A. Ismail, Curr. Opin. Food Sci., 2016, 8, 56-61.
5 T. Chen, Q. Gui, J. J. Shi, X. Y. Zhang and F. S. Chen, Acetic Acid Bact, 2013, 2, 6.

6 M. Valko, D. Leibfritz, J. Moncol, M. T. D. Cronin, M. Mazur and J. Telser, Int. J. Biochem. Cell Biol., 2007, 39, 44-84.

7 K. Oettl, V. Stadlbauer, F. Petter, J. Greilberger, C. PutzBankuti, S. Hallström, C. Lackner and R. E. Stauber, Biochim. Biophys. Acta, Mol. Basis Dis., 2008, 1782, 469-473.

8 L. A. Videla, World J. Hepatol., 2009, 31, 72-78.

9 B. Poljsak and I. Milisav, Oxid. Med. Cell. Longevity, 2013, 2013, 956792.

10 P. D. Ray, B. W. Huang and Y. Tsuji, Cell. Signalling, 2012, 24, 981-990.

11 W. Dröge, Physiol. Rev., 2002, 82, 47-95.

12 S. Kovac, P. R. Angelova, K. M. Holmström, Y. Zhang, A. T. Dinkova-Kostova and A. Y. Abramov, Biochim. Biophys. Acta, Gen. Subj., 2015, 1850, 794-801.

13 H. Tanaka, T. Nishi and Y. Wada, J. Biol. Chem., 2009, 284, 13291-13295.

14 G. M. DeNicola, F. A. Karreth, T. J. Humpton, A. Gopinathan, C. Wei, K. Frese, D. Mangal, K. H. Yu, C. J. Yeo, E. S. Calhoun, F. Scrimieri, J. M. Winter, R. H. Hruban, C. L. Donahue, S. E. Kern, L. A. Blair and D. A. Tuveson, Nature, 2011, 475, 106-109.

15 H. Chen, Y. Zhou, Y. Shao and F. Chen, Int. J. Food Prop., 2016, 19, 1183-1193.

16 E. Verzelloni, D. Tagliazucchi and A. Conte, Food Chem., 2007, 105, 564-571.

17 A. Piva, C. D. Mattia, L. Neri, G. Dimitri, M. Chiarini and G. Sacchetti, Food Chem., 2008, 106, 1057-1065.

18 S. Nishidai, Y. Nakamura, K. Torikai, M. Yamamoto, N. Ishihara, H. Mori and H. Ohigashi, Biosci., Biotechnol., Biochem., 2000, 64, 1909-1914.

19 M. Lizuka, M. Tani, Y. Kishimoto, E. Saita, M. Toyozaki and K. Kondo, J. Nutr. Sci. Vitaminol., 2010, 56, 421-427.

20 J. Xiang, W. Zhu, Z. Li and S. Ling, Food Funct., 2012, 3, 628634.

21 N. E. Mohamad, S. K. Yeap, K. L. Lim, H. M. Yusof, B. K. Beh, S. W. Tan, W. Y. Ho, S. A. Sharifuddin, A. Jamaluddin, K. Long, N. M. A. NikAbdRahman and N. B. Alitheen, Chin. Med., 2015, 10, 3.

22 D. J. Lamport, Nutr. Aging, 2012, 1, 5-25.

23 C. H. Chou, C. W. Liu, D. J. Yang, Y. H. S. Wu and Y. C. Chen, Food Chem., 2015, 168, 63-69.

24 S. I. F. S. Martins, W. M. F. Jongen and M. A. J. S. V. Boekel, Trends Food Sci. Technol., 2001, 11, 364-373.

25 M. F. Di, V. Lemaur, J. Cornil, R. Lazzaroni, J. L. Olivier and P. Trouillas, J. Phys. Chem. A, 2013, 117, 2082-2092.

26 M. M. Silva, M. R. Santos, G. Caroco, R. Rocha, G. Justino and L. Mira, Free Radical Res., 2009, 36, 1219-1227.

27 D. Tagliazucchi, E. Verzelloni and A. Conte, J. Food Biochem., 2010, 34, 1061-1078.

28 F. M. Campos, A. R. Figueiredo, T. A. Hogg and J. A. Couto, Food Microbiol., 2009, 26, 409-414.

29 R. L. Prior, X. Wu and K. Schaich, J. Agric. Food Chem., 2005, 53, 4290-4302.

30 B. Ou, D. Huang, M. Hampsch-Woodill, J. A. Flanagan and E. K. Deemer, J. Agric. Food Chem., 2002, 50, 3122-3128. 
31 D. Bertelli, A. Maietti, G. Papotti, P. Tedeschi, G. Bonetti, R. Graziosi, V. Brandolini and M. Plessi, Food Anal. Method., 2015, 8, 371-379.

32 R. van den Berg, G. R. M. M. Haenen, H. van den Berg and A. Bast, Food Chem., 1999, 66, 511-517.

33 N. Baba, Y. Higashi and T. Kanekura, Nutr. Cancer, 2013, 65, 1093-1097.

34 H. Zhao, W. Meng, S. Yi and G. Chen, Ogr. Transpl., 2014, 5, 242-250.

35 P. Kaczara, T. Sarna and J. M. Burke, Free Radical Biol. Med., 2010, 48, 1064-1070.

36 X. Zhang, L. Wang, R. Wang, X. Luo, Y. Li and Z. Chen, Food Funct., 2016, 7, 1429-1437.

37 H. Y. Chen, X. Zhang, S. F. Chen, Y. X. Zhang, Y. H. Liu, L. L. Ma and L. X. Wang, Biomed. Pharmacother., 2012, 66, 57-63.

38 M. Schieber and N. S. Chandel, Curr. Biol., 2014, 24, R453R462.

39 O. I. Aruoma, J. Am. Oil Chem. Soc., 1998, 75, 199-212.

40 R. Rodriguez and R. Redman, Proc. Natl. Acad. Sci. U. S. A., 2005, 102, 3175-3176.

41 W. H. Park, Int. J. Mol. Med., 2012, 31, 471-476.

42 S. Gaweł, M. Wardas, E. Niedworok and P. Wardas, Wiad. Lek., 2004, 57, 453-455.

43 S. W. Ryter, H. P. Kim, A. Hoetzel, J. W. Park, K. Nakahira, X. Wang and A. M. K. Choi, Antioxid. Redox Signaling, 2007, 9, 49-89.

44 S. Marchi, C. Giorgi, J. M. Suski, C. Agnoletto, A. Bononi, M. Bonora, E. De Marchi, S. Missiroli, S. Patergnani,
F. Poletti, A. Rimessi, J. Duszynski, M. R. Wieckowski and

P. Pinton, J. Signal Transduction, 2012, 2012, 329635.

45 G. Ashrafi and T. L. Schwarz, Cell Death Differ., 2013, 20, 3142.

46 J. M. Suski, M. Lebiedzinska, M. Bonora, P. Pinton, J. Duszynski and M. R. Wieckowski, Methods Mol. Biol., 2012, 810, 183-205.

47 Q. Cheng, G. Yang, J. Ma, J. Li and Q. Shan, Exp. Ther. Med., 2014, 7, 335-342.

48 M. C. Chen, Y. Y. Ye, G. Ji and J. W. Liu, J. Agric. Food Chem., 2010, 58, 3330-3335.

49 M. J. Czaja, Semin. Liver Dis., 2007, 27, 378-389.

50 B. Halliwell, Nutr. Rev., 2012, 70, 257-265.

51 T. Finkel and N. J. Holbrook, Nature, 2000, 408, 239-247.

52 J. P. Kehrer and L. G. Lund, Free Radical Biol. Med., 1994, 17, 65-75.

53 W. Li and A. N. Kong, Mol. Carcinog., 2009, 48, 91-104.

54 W. O. Osburn, N. Wakabayashi, V. Misra, T. Nilles, S. Biswal, M. A. Trush and T. W. Kensler, Arch. Biochem. Biophys., 2006, 454, 7-15.

55 X. L. Chen and C. Kunsch, Curr. Pharm. Des., 2004, 10, 879891.

56 T. W. Kensler, N. Wakabayashi and S. Biswal, Annu. Rev. Pharmacol. Toxicol., 2007, 47, 89-116.

57 A. Martínez-Hernández, E. J. Córdova, O. Rosillo-Salazar, H. García-Ortíz, C. Contreras-Cubas, S. Islas-Andrade, C. Revilla-Monsalve, C. Salas-Labadía and L. Orozco, PLoS One, 2015, 10, e0123313.

58 M. Kobayashi and M. Yamamoto, Antioxid. Redox Signaling, 2005, 7, 385-394. 